Art. $\mathrm{n}^{\circ} 62$

Contribution $\mathrm{COB} \mathrm{n}^{\circ} 57$

\title{
WESTERN EXTENSION OF BOUNDARY BETWEEN EUROPEAN AND !BERIAN PLATES DURING THE PYRENEAN OROGENY*
}

\author{
Xavier LE PICHON and Jean-Claude SIBUET \\ Centre Océanologique de Bretagne, B.P. 337, Brest, France
}

Received 25 June 1971

\begin{abstract}
- The kinematics of the Eocene episode of compression between the Iberian and European plates is examined. It is proposed that the boundary between the two plates extended west of the Pyrenees, along the Spanish marginal trench to end west of King's trough at a triple point junction. The pole of relative rotation computed within this hypothesis lies near $-59^{\circ} \mathrm{N} ; 62^{\circ} \mathrm{W}$ and the resulting shortening along the Pyrenees is about $50 \mathrm{~km}$ along $45^{\circ} \mathrm{E}$.
\end{abstract}

\section{Introduction}

An analysis of geological and geophysical data in the deep portions of the Bay of Biscay, on its continental margins and on the adjacent continents [1-3] has lead Le Pichon et al. [4] to propose an hypothesis for the evolution of the Bay of Biscay within the framework of plate tectonics. In this hypothesis, the Iberian peninsula would have rotated away from Europe about a pole located to the northeast of Paris, during a Mesozoic spreading episode, creating the Bay of Biscay. Later, the structural framework would have been modified during an Eocene episode of compression. The purpose of this paper is to examine more closely the kinematics of the Eocene tectonic episode of compression.

The parameters of the rotation of the Iberian plate relative to the European plate during the first phase were determined by assuming that breaks in the magnetic pattern within the Bay of Biscay and major faults on the continents were along transform directions (see fig. 1). This $30^{\circ}$ rotation resulted in an opening in the Bay and in pure strike slip along the North Pyrenean fault, which was part of the boundary between the European and Iberian plates. Le Pichon et al. have shown that this hypothesis is compatible

\footnotetext{
* Contribution no. 57 of the Groupe Scientifique du Centre Océanologique de Bretagne.
}

with the fact that no compression occurred in the Pyrenees during the Mesozoic.

The episode of distension ended in Late Cretaceous and was followed by an episode of compression during which the main phase of creation of the Pyrenean mountains occurred. This main orogenic phase, in the Pyrenees, is well dated as Upper Eocene (45 to $38 \mathrm{my}$ ago). It is marked by important folding accompanied by northward thrusts of great amplitude. Mattauer [5] has shown that the structures are essentially cylindrical and that the magnitude of shortening is of the order of $50 \pm 20 \mathrm{~km}$. Thus, one has to conclude that this orogenic phase was due to a northward movement of the Iberian plate with respect to the European plate.

Where is the westward extension of the compressive boundary between the two plates which lay along the Pyrenees during the Eocene?

\section{Northern Spanish marginal trench}

Bacon and Gray [6] have shown the existence of a marginal trench at the foot of the North-Spanish continental margin. Sibuet and Le Pichon [2], Sibuet et al. [3], Sichler et al. [1] and Montadert et al. [7] have shown that in this EW trench (along CD in fig. 2), which is filled with sediments, the basement is about $11 \mathrm{~km}$ deep, instead of $7.5 \mathrm{~km}$ under the adjacent 


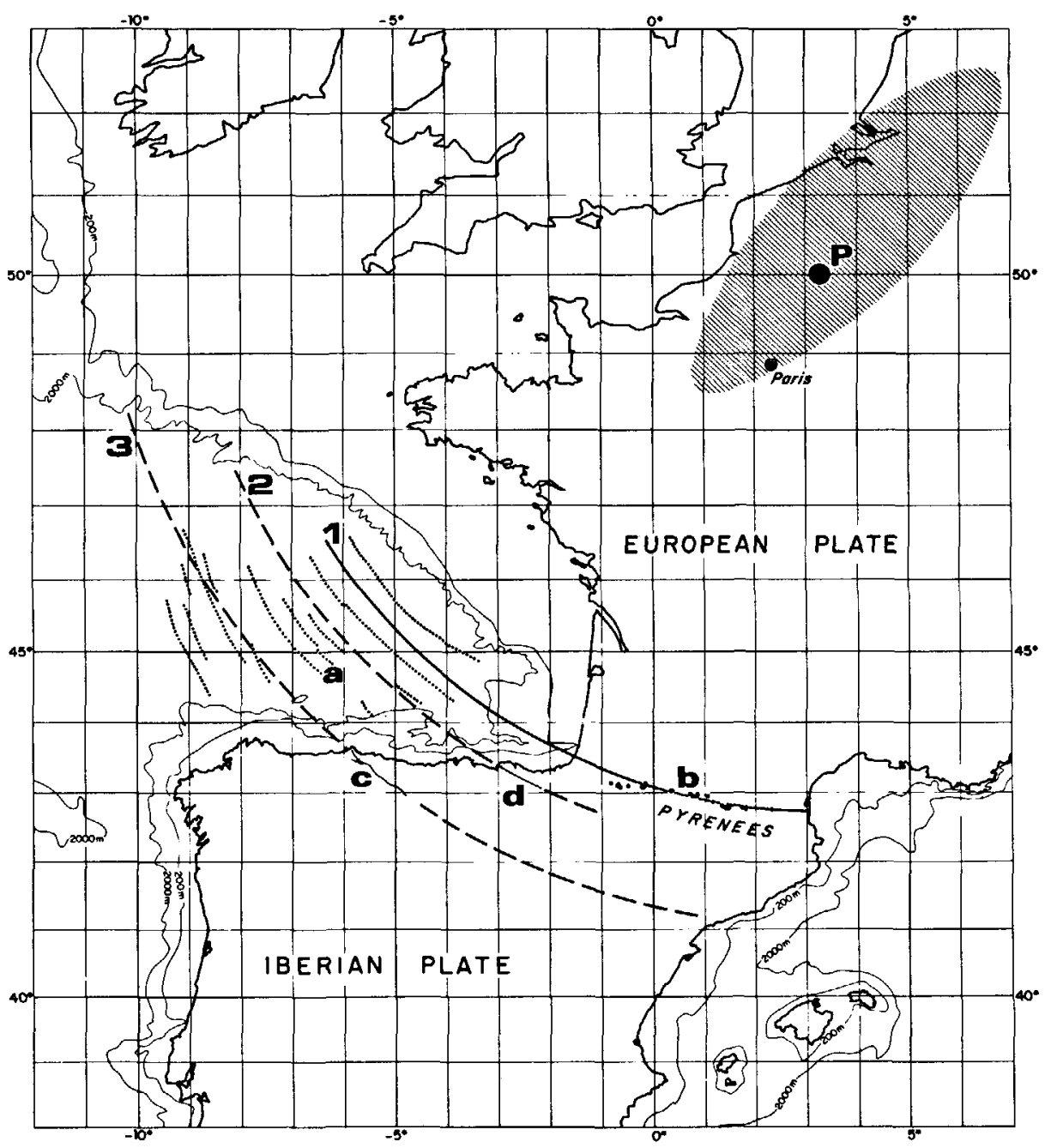

Fig. 1. $95 \%$ oval of confidence around the best fit pole $P\left(50^{\circ} \mathrm{N} ; 3.3^{\circ} \mathrm{E}\right)$ of relative rotation between the Iberian plate and the European plate during the opening of the Bay of Biscay, 1, 2 and 3 are small circles about the pole $P$ corresponding respectively to the North Pyrenean transform fault and the Biscaye and Oviedo transform directions where a limited amount of strike slip movement probably occurred along prolongations of transform faults [4]. (a) Major breaks in the magnetic anomaly pattern, (b) lherzolite outcrops defining the location of the North Pyrenean fault [13], (c) Oviedo fault, (d) axis of Biscaye synclinorium.

abyssal plain. Like the Pyrenees, it is a cylindrical structure which has a constant width of about $100 \mathrm{~km}$ along its $400 \mathrm{~km}$ length. The Southern part of the trench is occupied by tectonized diapiric structures, corresponding to the evaporitic layer found on each side of the abyssal plain at the foot of the continental rise. Boillot et al. [8] have shown that the adjacent northern Spanish continental margin has been folded along EW directions during the Eocene. Thus, it is probable that this trench was active during the Eocene, decoupling the Iberian block from the oceanic crust north of it.

Le Pichon et al. [4] concluded that during the Eocene the North Spanish marginal trench was joined to the Pyrenees by a trench-orogen transform fault in the general area of the Santander canyon, near BC in 


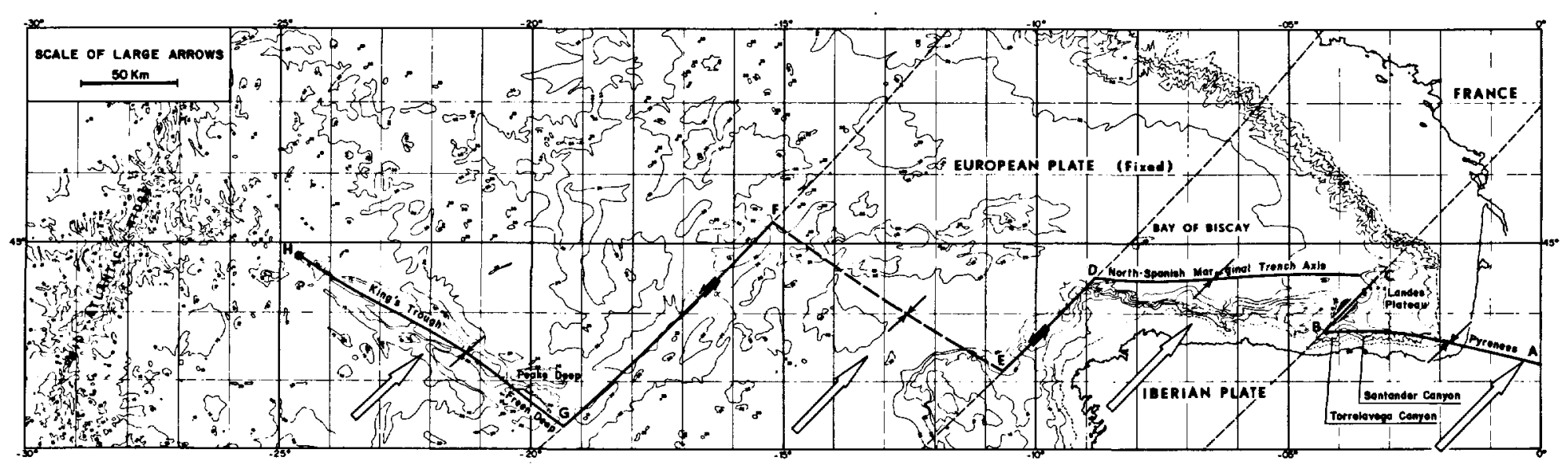

20.

Fig. 2. Bathymetry of the Bay of Biscay and the Western approaches to the Mid Atlantic ridge simplified after Laughton [12]. Contours in hundreds of nominal fathoms at $500 \mathrm{fm}$ interval. ABCDEFGH is the limit between Iberian and European plates during Eocene time. $H$ is the triple point junction. BC, ED, GF are trench-trench transform faults. Dashed lines are small circles about the Eocene pole of relative rotation $\left(59^{\circ} \mathrm{N} ; 62^{\circ} \mathrm{W}\right)$. Large arrows show the amount of compression along the plate boundary during this episode. 
fig. 2. This conclusion is reinforced by the fact that the marginal trench ends abruptly near point $C$ against the Landes marginal plateau to the East.

\section{Western extension of the plate boundary}

Within the plate tectonics hypothesis, this plate boundary should extend towards the West to the crest of the Eocene mid Atlantic ridge to end there at a triple point junction [9] (junction of the American, European and Iberian Plates). Thus, the extension of the plate boundary west of the Spanish trench should mark the morphology of the oceanic basin.

Matthews et al. and Cann and Funnell [10] have described deep troughs, called King's Trough and Peake and Freen Deeps, between $\mathrm{G}$ and $\mathrm{H}$ in fig. 2, extending NW-SE on the flanks of the Mid Atlantic ridge, at the latitude of the Spanish trench. They have shown that these troughs probably do not mark the site of a transform fault as there is no important offset of the ridge crest along their prolongation and as they end abruptly $200 \mathrm{~km}$ east of the present Rift Valley. They have interpreted the structures as resulting from overthrusting perpendicular to the deeps. They suggest that the opening of the deeps occurred 26 my ago on the basis of $\mathrm{K}-\mathrm{Ar}$ ages of retrograded amphibolites. They noted that this age seems to be confirmed by the difference between Lower and Middle Tertiary sediments and Upper Tertiary sediments. Pitman and Talwani [11] have mapped the magnetic anomalies in this area and their results show that point $\mathrm{H}$, which is the western end of the troughs. lies near the $40 \mathrm{my}$ isochron. The simplest explanation of these troughs is that they are the western equivalent of the Spanish trench and that point $\mathrm{H}$ was the location of the triple point junction at the time the compression ended at the end of Upper Eocene. This explains the abrupt western termination of the troughs. However, the main Eocene phase of overthrusting 40 my ago may have been followed by a phase of mostly vertical tectonics in Lower Miocene to Upper Oligocene, if the conclusions of Cann and Funnell are exact. Such an episode is known in the Bay of Biscay $[3,4,8]$.

An excellent bathymetric map of Laughton [12] gives sufficient indications to trace the probable path of the Eocene plate boundary between $G$ and $D$ in fig. 2. If $A B$ (Pyrenees), $C D$ (marginal Spanish trench) and GH (King's Trough and Peake and Freen Deeps) are zones of compression, we have to interpret $\mathrm{EF}$ as a zone of compression too and $\mathrm{BC}, \mathrm{ED}$ and $\mathrm{GF}$ as zones where strike slip is dominant. GF lies along what Matthews et al. [10] have described as the AzoresBiscay rise. It is a single crested rise, against which Peake and Freen Deeps end. It is specially well developed between $41^{\circ}$ and $45^{\circ} \mathrm{N}$ and thus apparently extends beyond $G$. This suggests that the strike slip movement between $\mathrm{G}$ and $\mathrm{F}$ may not have been entirely absorbed in the trench GH but that part of it was absorbed further south.

The bathymetric trends are not as clear along line EF and it is quite possible that the tracing of the plate boundary between $\mathrm{E}$ and $\mathrm{F}$ is more complex. The filling by turbidity currents has obliterated the topographic expression of this hypothetical portion of the trench which may actually lie further north. We unfortunately know very little about the structure and geology of the GF and FE portions of boundary. ED is the western extension of the Spanish marginal trench. Sibuet et al. [3] have shown that it has the same structure as further east but that it lies along a different NE-SW direction between $9^{\circ} \mathrm{W}$ and $12^{\circ} \mathrm{W}$. They showed further that the sedimentary layers are undisturbed, except for the presence of large untectonized diapirs. The absence of the tectonization can be interpreted if the movement is not compression but pure strike-slip.

\section{Determination of the parameters of rotation}

If we accept the interpretation of GF, ED and BC as pure strike slip, we can compute the location of the Eocene pole of relative rotation by assuming that $\mathrm{GF}, \mathrm{ED}$ and $\mathrm{BC}$ lie along small circles about this pole. The computation minimizes the distance between the points chosen along these lines and small circles. The actual points were chosen on the basis of the continuity of bathymetric trends. The standard deviation of these points about the theoretical small circles is $4 \mathrm{~km}$. The computed pole lies near $59^{\circ} \mathrm{N} ; 62^{\circ} \mathrm{W}$. It is not well determined. The pole being rather far to the west ( $4500 \mathrm{~km}$ away from the Pyrenees), the amount of relative movement changes little along the boundary which is compatible with the cylindricity of the structures. If we accept the interpretation of the Pyrenees 
as resulting from a $50 \mathrm{~km}$ shortening, the angle of rotation computed with these parameters. Note that the direction of compression is slightly oblique to the Pyrenees, making an angle of $60^{\circ}$ with their axis.

\section{Consequence of the hypothesis}

Fig. 3 shows the relative position of the Iberian plate before the Cenozoic compressive phase. It can be seen that ignoring this movement does not affect significantly the determination of the Mesozoic pole of opening of the Bay of Biscay. This is due to the very small amount of Eocene rotation.

The hypothesis we have proposed can be tested by a detailed survey of the western prolongation of this hypothetical Eocene plate boundary and by confrontation with data concerning the tectonics of the Pyrenean main orogenic phase. If it is true, it provides a way to date very precisely the end of the main Pyrenean phase by dating the age of the ocean floor at the triple point junction $H$.

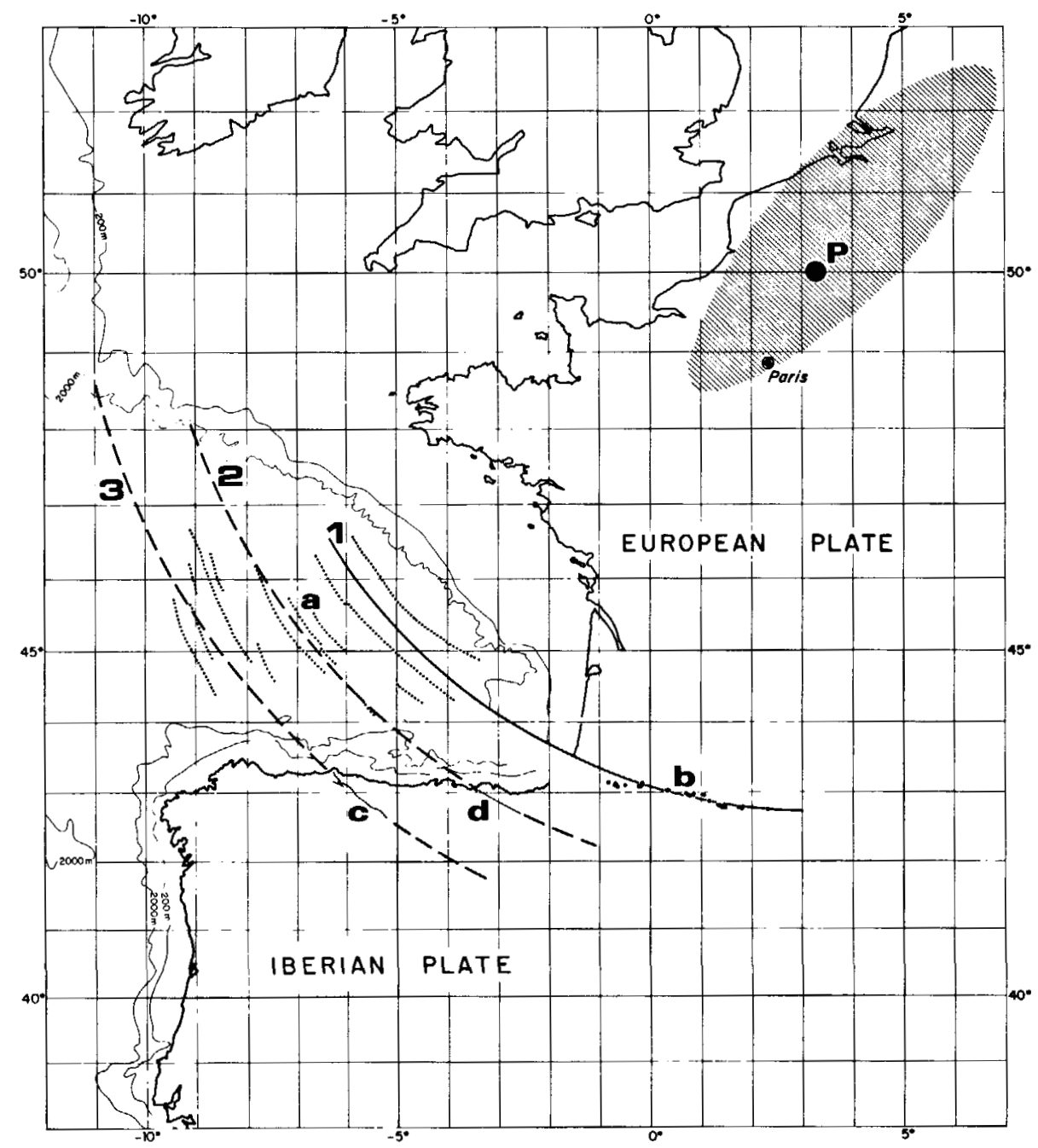

Fig. 3. The Iberian plate has been replaced in its pre-Eocene position with respect to the European plate. Symbols as in fig. 1. This small change does not affect significantly the computation of the pole and of the ovale of confidence. 


\section{Acknowledgements}

We are grateful to A.S.Laughton for making his bathymetric map available to us and to W.Pitman and M.Talwani for sending us a paper in advance of publication. J.Francheteau critically read the paper.

\section{References}

[1] B.Sichler, J.Martinais, J.C.Sibuet and X.Le Pichon, Vitesse des ondes sismiques dans les couches sédimentaires profondes du golfe de Gascogne, Symposium sur l'histoire structurale du golfe de Gascogne, Rueil-Malmaison, December 1970 (in press).

[2] J.C.Sibuet and X.Le Pichon, Structure gravimétrique du golfe de Gascogne et le fossé marginal nord-espagnol, Symposium sur l'histoire structurale du golfe de Gascogne, Rueil-Malmaison, December 1970.

[3] J.C.Sibuet, G.Pautot and X.Le Pichon, Interprétations structurales du golfe de Gascogne à partir des profils sismiques, Symposium sur l'histoire structurale du golfe de Gascogne, Rueil-Malmaison, December 1970 (in press).

[4] X.Le Pichon, J.Bonnin, J.Francheteau and J.C.Sibuet, Une hypothèse d'évolution tectonique du golfe de Gascogne, Symposium sur l'histoire structurale du golfe de Gascogne, Rueil-Malmaison, December 1970 (in press).
[5] M.Mattauer, Les traits structuraux essentiels de la chaîne pyrénéenne, Rev. Geogr. Phys. Geol. Dyn. 10 (1968) 3.

[6] M.Bacon, F.Gray and D.H.Matthews, Crustal structures studies in the Bay of Biscay, Earth Planet. Sci. Letters 6 (1969) 377.

[7] L.Montadert, B.Damotte, J.Deby ser, J.P.Fail, J.R.Delteil and P.Valery, Continental margin in the Bay of Biscay, S.C.O.R.Symposium on the Geology of the East Atlantic Continental Margin, Cambridge, March 1970 (in press).

[8] G.Boillot, P.A.Dupeuble, M.Lamboy, L.D'Ozouville and J.C.Sibuet, Etude structurale de la marge continentale nord-espagnole entre $4^{\circ} \mathrm{W}$ et $9^{\circ} \mathrm{W}$, Symposium sur I'histoire structurale du golfe de Gascogne, Rueil-Malmaison, December 1970 (in press).

[9] D.P.MacKenzie and W.J.Morgan, The evolution of Triple Junctions, Nature 224 (1969) 125.

[10] D.H.Matthews, A.S.Laugh ton, D.T.Pugh, E.J.W.Jones, J.Sunderland, M.Takin and M.Bacon, Crustal structure and origin of Peake and Freen Deeps, N.E. Atlantic. Geophys. J. 18 (1969) 517;

J.R.Cann and B.M.Funnell, Palmer ridge: a section through the Upper part of the Ocean Crust, Nature 213 (1967) 661.

[11] W.C.Pitman and M.Talwani, Sea floor spreading in the North Atlantic, Geol. Soc. Am. Bull. (in press).

[12] A.S.Laughton, Bathymetric contour charts (unpublished).

[13] P.Monchoux, Les lherzolites pyrénéennes: contribution à l'étude de leur minéralogie, de leur genèse et de leurs transformations, Thesis, Paul Sabatier University, Toulouse (1970). 